\title{
Pemberian Pupuk Organik Cair (Urin Sapi) terhadap Tinggi Pennisetum purpureum cv. Mott.
}

\author{
The Effect of Liquid Organic Fertilizer (Urine of Cattle) to the Height \\ of Pennisetum purpureum cv. Mott)
}

\author{
Rasyidah Mappanganro*, Khaerani Kiramang, Muh. Dadang Kurniawan \\ Jurusan Ilmu Peternakan Fakultas Sains dan Teknologi \\ Universitas Islam Negeri Alauddin \\ *Korespondensi E-mail : Rosidahmappanganro@gmail.com
}

\begin{abstract}
ABSTRAK
Penelitian ini bertujuan untuk mengetahui pengaruh pemberian pupuk organik cair dari urin sapi terhadap tinggi tanaman rumput gajah mini. Penelitian ini menggunakan rancangan acak lengkap4 perlakuan dan 3 ulangan. Parameter dalam penelitian ini yaitu tinggi tanaman. Penelitian menggunakan rumput gajah mini sebanyak 28 rumpun, yang diberi pemupukan 7 hari setelah penyeragaman dengan dosis yang telah ditentukan antara 100-250 mL. Berdasarkan analisis sidik ragam (ANOVA) dari RAL menunjukkan bahwa pemberian pupuk organik cair (POC) terhadap pertumbuhan rumput gajah mini berpengaruh nyata $(\mathrm{P}<0,05)$ terhadap tinggi tanaman rumput gajah mini. Pertumbuhan pada perlakuan P3 cenderung lebih baik dan berbeda dengan perlakuan P0, P1 dan P2. Hal ini menunjukkan bahwasemakin tinggi dosis pemupukan maka pertumbuhan tinggi tanaman rumput gajah mini semakin meningkat.
\end{abstract}

Kata kunci: Pupuk Organik Cair, Rumput Gajah Mini, Tinggi Tanaman

\begin{abstract}
This research were aimed to determine the effect of applying liquid organic fertilizer from urine of cattle to the height of Pennisetum purpureum cv.Mott. This study used a completely randomized design of 4 treatments and 3 replications. The parameters in this study are plant height. Research using 28 dwarf elephant grasses, which were given fertilization 7 days after uniformity with a predetermined dose between $100 \mathrm{ml}-250 \mathrm{ml}$. Based on the analysis of variance (ANOVA) of RAL, it was shown that the applying of liquid organic fertilizer on the growth of dwarf elephant grass had a significant effect $(P<0.05)$ to the height of dwarf elephant grass plants. Growth in P3 treatment tends to be better and different with treatment P0, P1 and P2. This shows that the higher the fertilizer dosage, the higher the growth of dwarf elephant grass plants.
\end{abstract}

Keywords: Liquid Organic Fertilizer, Plant Height, Pennisetum purpureum 


\section{PENDAHULUAN}

Indonesia termasuk kedalam wilayah iklim tropis. Tumbuh-tumbuhan yang dapat hidup di wilayah iklim sub-tropis belum tentu dapat hidup dengan baik di wilayah iklim tropis dan sebaliknya. Komponen iklim yang paling besar pengaruhnya terhadap hasil dan mutu hijauan pakan ternakdi Indonesia adalah curah hujan dan suhu udara Curah hujan, pada musim hujan produksi hijauan pakan ternak biasanya tinggi, tetapi kemungkinan mutunya akan menurun, hal ini disebabkan karena musim hujan pertumbuhannya lebih cepat dari pada musim kemarau, akibatnya peternak kelebihan pasokan sehingga banyak rumput yang terlambat di potong. apabila rumput dipotong terlalu tua, kandungan serat kasarnya meningkat, sedangkan kandungan protein kasarnya menurun (Badan Litbang Pertanian, 2014).

Rumput gajah mini merupakan jenis rumput unggul yang mempunyai produktivitas dan kandungan zat gizi yang cukup tinggi serta memiliki palatabilitas yang tinggi bagi ternak ruminansia. Rumput ini dapat hidup diberbagai tempat, respon terhadap pemupukan dan terus menghasilkan anakan apabila dipangkas secara teratur. Keunggulan rumput gajah mini yaitu batang relatif pendek dan empuk, pertumbuhannya relatif cepat, daun lembut dan tidak berbulu, dalam satu rumpun terdapat 50-80 batang dan sangat sangat disukai ternak ruminansia dibandingkan rumput lainnya (Widodo, 2015). Tanah merupakan media tanam bagi pertumbuhan dan perkembangan tanaman. Unsur hara yang dibutuhkan tanaman diperoleh dari tanah hasil dari dekomposisi bahan organik yang akan memperbaiki kesuburan fisik, kimia dan biologi tanah. Ketersediaan unsur hara tanah di daerah tropis tidak dapat mencukupi kebutuhan tanaman untuk pertumbuhan dan produksi, sehingga perlu penambahan pupuk sebagai sumber unsur hara. Rumput gajah mini menggunakan pupuk organik cair dariurine sapi merupakan suatu bentuk integrasi antara ternak dengan hijauan, dimanaurine sapi dimanfaatkan untuk meningkatkan pertumbuhan dan produksi hijauan.

Pupuk organik cair adalah larutan dari hasil pembusukan bahan-bahan organikyang berasal dari sisa tanaman, kotoran hewan dan manusia yang kandungan unsur haranya lebih dari satu unsur. Urine adalah zat-zat yang disekresikan melalui ginjal, zat-zat yang terdapat didalamnya berupa zat-zat makanan yang telah dicerna, diserap dan bahkan telah dimetabolisme oleh sel-sel tubuh, kemudian dikeluarkan melalui ginjal dan saluran urine. Urin mempunyai zat pengatur tumbuh dan mempunyai sifat penolak hama atau penyakit 
tanaman.Urin sapi bisa dibuat pupuk cair dengan menambahkan bahan-bahan tambahan seperti lengkuas, kunyit, temu ireng, jahe, kencur, brotowali. Bahan-bahan tadi berfungsi untuk menghilangkan bau urine sapi. Sedangkan untuk tetes tebu berfungsi untuk fermentasi dan menyuburkan mikroorganisme yang ada didalam tanah, tetes tebu ini sendiri mengandung bakteri Sacharomyces Sereviceae yang berfungsi untuk fermentasi (Setiawan, 2010).

Penggunaan limbah urine sebagai salah satu pupuk organik memberikan hasil yang cukup menjanjikan, sehingga peternak sudah bisa memperoleh hasil sebelum ternak itu dijual. Harga urine yang sudah diolah dan menjadi pupuk cair, berkisar antara Rp 7.000 - Rp 8.000/liter. Penggunaan urine ini sangat berpotensi, sehingga perlu memberdayakan peternak agar semua produk dari ternak bisa digunakan untuk mendatangkan keuntungan secara ekonomis, meski awalnya perlu ada pendampingan terhadap peternak, terutama soal teknik atau cara menampung urine hingga proses pembuatan menjadi pupuk cair (Hadisuwito, 2012).Pupuk organik cair kebanyakan diaplikasikan melalui daun atau disebut sebagai pupuk cair Foliar yang mengandung hara makro dan mikro esensial (N, P, K, S, Ca, $\mathrm{Mg}, \mathrm{B}, \mathrm{Mo}, \mathrm{Cu}, \mathrm{Fe}, \mathrm{Mn}$ dan bahan organik). Pupuk organik cair selain dapat memperbaiki sifat fisik, kimia dan biologi tanah, juga membantu meningkatkan produksi tanaman, meningkatkan kualitas produk tanaman, mengurangi penggunaan pupuk anorganik dan sebagai alternatif pengganti pupuk kandang.

Beberapa manfaat lain dari pupuk organik cair diantaranya dapat mendorong dan meningkatkan pembentukan klorofil daun dan pembentukan bintil akar pada tanaman leguminosae sehingga meningkatkan kemampuan fotosintesis tanaman dan penyerapan nitrogen dari udara, dapat meningkatkan vigor tanaman sehingga tanaman menjadi kokoh dan kuat, meningkatkan daya tahan tanaman terhadap kekeringan, cekaman cuaca dan serangan patogen penyebab penyakit, merangsang pertumbuhan cabang produksi, meningkatkan pembentukan bunga dan bakal buah dan mengurangi gugurnya daun, bunga dan bakal buah (Yuanita 2010).

Dengan penguraian diatas maka dipandang perlu untuk melakukan penelitian terhadap pengaruh pemberian pupuk organik cair terhadap tinggi rumput gajah mini (Pennisetum purpureum cv.Mott) dengan beberapa dosis yang berbeda. 
Sesuai dengan perumusan masalah, maka tujuan dalam penelitian ini adalahmengetahui pengaruh pemberian pupuk organik cair terhadap tinggi rumput gajah mini (Pennisetum purpureum cv.Mott) dengan beberapa dosis yang berbeda.

\section{METODE}

Penelitian ini menggunakan Rancangan Acak Lengkap (RAL) dengan 4 perlakuan dan 3 ulangan, perlakuan terdiri atas:

$$
\begin{aligned}
& 0=\text { rumput gajah mini (kontrol) } \\
& 1=\text { rumput gajah mini }+ \text { pupuk organik cair } 100 \mathrm{~mL} \\
& 2=\text { rumput gajah mini + pupuk organik cair } 150 \mathrm{~mL} \\
& 3=\text { rumput gajah mini + pupuk organik cair } 200 \mathrm{~mL}
\end{aligned}
$$

\section{Pembuatan Pupuk Organik Cair}

Bahan dasar untuk dijadikan sebagai pupuk cair (POC) yaitu urin sapi. Semua alat dan bahan disediakan terlebih dahulu, kemudian memasukkan bahan- bahan seperti urin sebanyak 40 liter, air kelapa sebanyak $600 \mathrm{~mL}$, molases $500 \mathrm{~mL}$ dan jamu herbal komersil sebanyak $1200 \mathrm{~mL}$ kedalam jergen. Jamu herbal dibuat dari campuran rempah-rempah seperti jahe, kencur, kunyit, lengkuas dan serai dengan komposisi masing-masing 0,4 kg.

Setelah penambahan jamu, diaduk sampai semua bahan di dalam jerigen tersebut homogen, kemudian dilakukan pengamatan awal, lalu jerigen ditutup rapat kemudian didiamkan selama 21 hari (fermentasi anaerob). Fermentasi urin ini dilakukan untuk mencegah kematian pada tanaman. Urin yang masih baru bisa menghanguskan tanaman karena kandungan unsur haranya masih sangat tinggi dan belum terurai sehingga belum mampu diserap secara langsung oleh tanaman.

\section{Kandungan Pupuk Organik Cair}

Pupuk organik cair yang digunakan dalam penelitian ini merupakan jenis pupuk yang bersumber dari bahan baku herbal $(1200 \mathrm{~mL})$ yang ditambahkan urin sapi (40 liter), air cucian beras $(1000 \mathrm{ml})$, air kelapa $(500 \mathrm{ml})$ dan molases $(500 \mathrm{ml})$ dan difermentasi selama 21 hari. Lokasi penelitian telah ditumbuhi rumput gajah mini dengan umur rumput 40 hari. Langkah pertama yang dilakukan pada penelitian ini yaitu membersihkan gulma yang ada diantara tanaman rumput gajah mini. Selanjutnya, dilakukan pemotongan penyeragaman sekitar $3 \mathrm{~cm}$ dari tanah dan pemupukan pada semua unit perlakuan dengan dosis sesuai 
dengan perlakuan yang telah ditentukan. Tahap ketiga yaitu pengambilan data di lokasi penelitian pada tanaman yang berumur 30 hari setelah pemupukan. Variabel yang diamati dalam penelitian ini adalah tinggi tanaman rumput gajah.

\section{Analisis Data}

Data yang diperoleh dianalisis dengan menggunakan software SPSS versi 16 dan diuji lanjut dengan menggunakan uji wilayah berganda Duncan (Gasperz, 1991).

\section{HASIL DAN PEMBAHASAN}

Hasil penelitianian pupuk organik cair terhadap pertumbuhan rumput gajah mini selama 37 hari disajikan pada Tabel 1.

Tabel 1. Hasil Analisis Tinggi Tanaman Rumput Gajah Mini dengan Pemberian Pupuk Organik Cair (POC) Selama 37 Hari.

\begin{tabular}{ccccc}
\hline \multirow{2}{*}{ Parameter } & \multicolumn{4}{c}{ Perlakuan } \\
\cline { 2 - 5 } & P0 & P1 & P2 & P3 \\
\hline Tinggi Tanaman (cm) & $47,33^{\mathrm{a}}$ & $65,67^{\mathrm{b}}$ & $74,4^{\mathrm{c}}$ & $82,6^{\mathrm{d}}$ \\
\hline Keterangan: Superskrip yang berbeda menunjukkan pengaruh yang nyata $(\mathrm{P}<0,05)$.
\end{tabular}

Berdasarkan hasil analisis memperlihatkan bahwa pengaruh pemberian pupuk organik cair terhadap tinggi tanaman rumput gajah mini berpengaruh nyata. Hal ini disebabkan karena pupuk organik cair yang digunakan pada pada padang rumput dapat memperbaiki sifat fisik, kimia dan biologis tanah, meningkatkan kualitas dan kontiunitas tanaman, karena kandungan nitrogennya yaitu sebesar 0,204 yang digunakan untuk pertumbuhan tunas, batang dan daun. Pupuk ini memiliki keistimewaan apabila dibandingkan dengan pupuk alam yang lain (pupuk kandang dan kompos), pupuk ini cepat diserap oleh tanaman. Hal ini sesuai dengan pendapat Wahid (2003), yang menyatakan bahwa bahan organik cair mempunyai peranan terhadap ketersedian unsur hara oleh karena itu tanaman sangat membutuhkan hal tersebut yang akan digunakan untuk pertumbuhan dan perkembangan seperti pertumbuhan daun dan batang. Bahwa pertumbuhan jumlah dan ukuran daun dipengaruhi oleh ketersedian unsur hara di dalam tanah. Menurut Nasaruddin (2010) bahwa pemberian pupuk sangat erat kaitannya dengan fase pertumbuhan vegetative dan generative. Nitrogen merupakan unsur hara utama bagi 
pertumbuhan tanaman pada umumnya yang sangat diperlukan untuk pembentukan atau pertumbuhan bagian-bagian vegetative tanaman seperti daun, batang dan akar.

Rata-rata tinggi tanaman rumput gajah mini pada masing-masing perlakuan dapat dilihat pada gambar 1. Hasil analisis keregamaan menunjukkan bahwa pemberian pupuk cair berpengaruh nyata $(\mathrm{P}<0,05)$ terhadap tinggi rumput gajah mini. Hasil uji lanjut menunjukkan bahwa semua perlakuan berpengaruh nyata terhadap pertumbuhan rumput gajah mini kecuali perlakuan P0 berbeda tidak nyata. Hal ini diduga karena pupuk yang diberikan antar masing-masing perlakuan menyediakan unsur Nitrogen, yang dibutuhkan dalam proses pembentukan protein tanaman sehingga meningkatkan pertumbuhan vegetatif tanaman seperti batang, daun dan akar. Hasil tersebut menunjukkan bahwa rumput gajah mini peka terhadap pupuk cair dengan dosis $200 \mathrm{ml}$. Hal ini terlihat dari peningkatan pertumbuhan tinggi rumput gajah mini seiring dengan peningkatan dosis pupuk cair $100 \mathrm{ml}$ hingga $200 \mathrm{~mL}$. Hal ini sesuai dengan pendapat Fahri (2016), yang menyatakan bahwa tanaman akan tumbuh dengan baik apabila unsur hara yang diberikan berada dalam jumlah yang seimbang dan sesuai dengan kebutuhan tanaman.

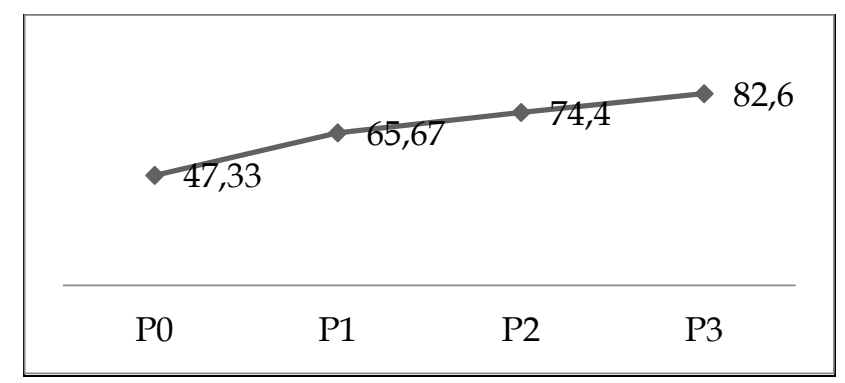

\section{Gambar 1. Rataan Tinggi Rumpu Gajah Mini}

Pupuk cair yang memiliki kandungan unsur hara mikro (N, P, K, S, Ca, Mg) dan mikro ( $\mathrm{B}, \mathrm{Mo}, \mathrm{Cu}, \mathrm{Fe}, \mathrm{Mn})$ dapat dilihat pada unsur nitrogen yang mempunyai peranan penting terhadap pertumbuhan rumput gajah mini. Hal ini sesuai dengan pendapat Sugi dkk (2011), yang menyatakan bahwa pupuk organik mempunyai banyak kelebihan, apabila dibandingkan dengan pupuk anorganik yaitu pupuk yang memiliki unsur hara yang lebih lengkap, baik unsur hara makro maupun unsur hara mikro dan pupuk organik mengandung asam-asam organik, enzim dan hormon yang tidak terdapat dalam pupuk buatan. 
Berdasarkan analisis sidik ragam (ANOVA)menunjukkan bahwa pemberian pupuk organik cair (POC) terhadap pertumbuhan rumput gajah mini berpengaruh nyata $(\mathrm{P}<0,05)$ terhadap tinggi tanaman rumput gajah mini pada tingkat kepercayaan 95\%. Berdasarkan uji Duncan diketahui bahwa semua perlakuan berbeda nyata. Tinggi rata-rata rumput gajah mini yaitu P0 $(47,33 \mathrm{~cm})$, P1 $(65,67 \mathrm{~cm})$, P2 $(74,4 \mathrm{~cm})$ dan P3 $(82,6 \mathrm{~cm})$. Tanaman paling tinggi terdapat pada sampel P3 $(82,6 \mathrm{~cm})$ berbeda dengan P0 $(47,33 \mathrm{~cm}), \mathrm{P} 1(65,67 \mathrm{~cm})$ dan P2 (74,4 cm). Perlakuan P3 jumlah pupuk yang diberikan lebih banyak daripada perlakuan lainnya, sehingga unsur hara yang tersedia dan dapat diserap oleh tanaman juga lebih banyak dibandingkan perlakuan lain. Hal ini sesuai dengan pendapat Fahri (2016), yang menyatakan bahwa pupuk adalah suatu bahan yang diberikan untuk memperbaiki kesuburan tanah dan mengganti unsur-unsur hara yang hilang dari tanah. Setiap jenis pupuk mempunyai kandungan unsur hara, kelarutan dan kecepatan kerja yang berbeda sehingga dosis dan jenis pupuk yang diberikan berbeda.

Hasil penelitian memperlihatkan bahwa pemberian pupuk organik cair (POC) mampu meningkatkan pertumbuhan rumput gajah mini disebabkan pupuk organik cair (POC) mampu meningkatkan unsur hara tanah sehingga unsur hara tanaman terpenuhi untuk proses pertumbuhan. Sejalan dengan pernyataan Hadisuwito (2012) bahwa kelebihan dari pupuk organik ini adalah dapat secara cepat mengatasi defesiensi hara, tidak bermasalah dalam pencucian hara, dan mampu menyediakan hara secara cepat. Dibandingkan dengan pupuk cair anorganik, pupuk organik cair umumnya tidak merusak tanah dan tanaman walaupun digunakan sesering mungkin. Selain itu, pupuk ini juga memiliki bahan pengikat, sehingga larutan pupuk yang diberikan kepermukaan tanah bisa langsung digunakan oleh tanaman.

Prinsip kerja pupuk organik dalam membantu proses pertumbuhan dimulai dari meningkatkan produktivitas tanah secara fisik, kimia dan biologi. Prinsip kerja pupuk organik cair dapat dilihat pada Tabel 1.

Pupuk organik merupakan pupuk yang berperan meningkatkan aktifitas biologi, kimia dan fisik tanah sehingga tanah menjadi subur dan baik untuk pertumbuhan tanaman. Saat ini sebagian besar petani masih tergantung pada pupuk anorganik karena mengandung beberapa unsur hara dalam jumlah yang banyak, padahal jika pupuk anorganik digunakan secara terus-menerus akan menimbulkan dampak negatif terhadap kondisi tanah (Indriani, 2004). 
Perbedaan keunggulan antara pupuk organik dan pupuk anorganik adalah sebagai yaitu pupuk organik mengandung unsur hara makro dan mikro lengkap, tetapi jumlahnya sedikit, dapat memperbaiki struktur tanah sehingga tanah menjadi gembur, memiliki daya simpan air (Water Holding Capacity) yang tinggi, beberapa tanaman yang di pupuk dengan pupuk organik lebih tahan terhadap penyakit/hama, meningkatkan aktivitas mikroorganisme tanah yang menguntungkan dan memiliki Residual Effect yang positif. Artinya pengaruh positif dari pupuk organik terhadap tanaman yang ditanam pada musim berikutnya masih ada sehingga pertumbuhan dan produktivitasnya masih bagus. Sedangkan pupuk anorganik hanya mengandung satu atau beberapa unsur hara, tetapi dalam jumlah banyak, tidak dapat memperbaiki struktur tanah, justru penggunaannya dalam jangka waktu panjang menyebabkan tanah menjadi keras, sering membuat tanaman rentan terhadap penyakit/hama dan pupuk anorganik mudah menguap dan tercuci. Karena itu, pengaplikasian yang tidak tepat akan sia-sia karena unsur hara yang ada hilang akibat menguap atau tercuci oleh air (Abdulgani, 2011).

Tabel 1. Prinsip Kerja Pupuk Organik Cair.

\begin{tabular}{|c|c|}
\hline Parameter & Prinsip Kerja Pupuk Organik \\
\hline \multirow{3}{*}{ Fisik } & Menggemburkan tanah \\
\hline & Meningkatkan kapasitas mengikat \\
\hline & Mencegah erosi dan longsor \\
\hline \multirow[t]{3}{*}{ Kimia } & Meningkatkan kapasitas tukar kation \\
\hline & Meningkatkan ketersediaan unsur hara \\
\hline & Meningkatkan proses pelapukan bahan mineral \\
\hline Biologi & $\begin{array}{l}\text { Menjadi sumber makanan bagi mikroorganisme tanah } \\
\text { seperti fungi, bakteri, serta mikroorganisme menguntungkan } \\
\text { lainnya, sehingga perkembangannya menjadi lebih cepat }\end{array}$ \\
\hline
\end{tabular}

Sumber: Hadisuwito, 2012.

\section{KESIMPULAN}

Berdasarkan hasil dan pembahasan bahwa pemberian pupuk organik cair (POC) berpengaruh nyata $(\mathrm{P}<0,05)$ terhadap tinggi tanaman dan luas daun pada pertumbuhan rumput gajah mini, semakin tinggi dosis pemupukan maka pertumbuhan tinggi tanaman dan luas daun rumput gajah mini semakin meningkat. Saran pada penelitian ini, yaitu perlunya penambahan dosis yang digunakan untuk mencari ambang batas dosis untuk menghasikan pertumbuhan rumput gajah mini yang lebih optimal. 


\section{DAFTAR PUSTAKA}

Abdulgani, I.K. 2011. Seluk Beluk Mengenai Kotoran Sapi Serta Manfaat Praktisnya. Institut Pertanian Bogor, Bogor.

Badan Litbang Pertanian. 2014. Faktor Utama yang Mempengaruhi Pertumbuhan dan Produksi Tanaman Pakan Ternak (TPT). http://balitnak.litbang.pertanian.go.id/ index.php?option=com_content\&view=article\&id=175:hpt\&catid=67:utm. (dikses tanggal 15 September 2017

Fahri, J. 2016. Pemanfaatan Pupuk CairTerhadap Pertumbuhan, Produksi dan Klorofil Rumput Gajah Mini pada Lahan Kering Kritis. Skripsi. Fakultas Peternakan, Universitas Hasanuddin, Makassar.

Gazperzs, V. 1991, Metode Rancangan Percobaan, Graha Mendia, Jakarta

Hadisuwito, S. 2007. Membuat Pupuk Kompos Cair. Agromedia Pustaka, Jakarta

Indriani. 2003. Petunjuk Penggunaan Pupuk. Penebar Swadaya, Jakarta.

Nasaruddin. 2010. Dasar-Dasar Fisiologi Tanaman. Fakultas Pertanian Universitas Hasanuddin dan Yayasan Forest Indonesia. Jakarta

Sugi R., Dyah P. dan Pujianto. 2011. Pemanfaatan Kotoran Ternak Sapi Sebagai Sumber Energi AlternatifRamah Lingkungan Beserta Aspek Sosio kulturalnya. http://journal.uny.ac.id/index.php/inotek/article/downloadSuppFile/38/29.pdf. (dikses tanggal 15 September 2017).

Setiawan, B. S. 2010. Membuat Pupuk Kandang secara Cepat. Jakarta: Penebar Swadaya.

Setiawan, A. I. 2012. Memanfaatkan Kotoran Ternak. Jakarta: Penebar Swadaya.

Wahid, A. S. 2003. Peningkatan efisiensi pupuk nitrogen pada padi sawah dengan metode bagan warna daun. Jurnal Litbang Pertanian. 22(4).

Widodo, K. 2015. Rumput Gajah Mini (Pennisetum purpureum cv. Mott). [serialonline].www.facebook.com/paguyubanpeternaksapinusantara. (diakses tanggal 15September 2017).

Yuanita, D. 2010. 'Cara Pembuatan Pupuk Organik Cair http:// staff.uny.ac.id/sites/default/files/pengabdian/dewi-yuanita-lestari-ssi$\mathrm{msc} /$ carapembuatan-pupuk-organik-cair.pdf.(diakses tanggal 15 September 2017). 